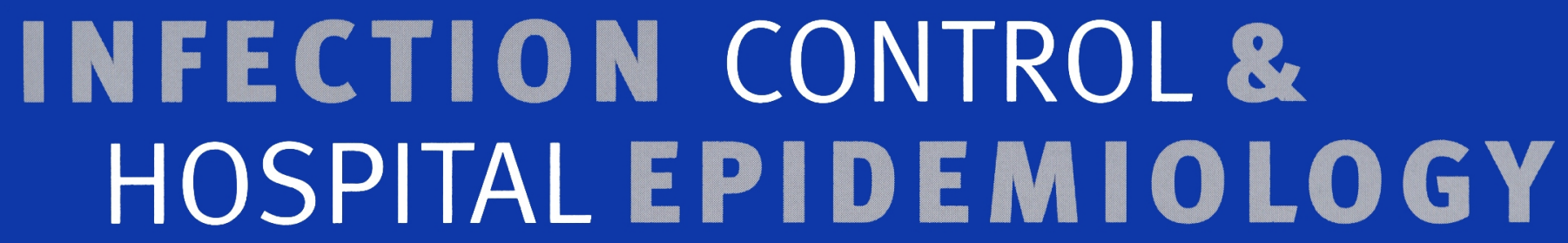

VOLUME 34, NUMBER 8

AUGUST 2013

ORIG INAL ARTICLES

Mucosal Barrier Injury Laboratory-Confirmed Bloodstream Infection: Results from a Field Test of a New National Healthcare Safety Network Definition • Isaac See, MD; Martha Iwamoto, MD, MPH;

Kathy Allen-Bridson, RN, BSN, MScPH; Teresa Horan, MPH; Shelley S. Magill, MD, PhD; Nicola D. Thompson, PhD, MS

Commentary: Improving the Central Line-Associated Bloodstream Infection Surveillance Definition: A Work in Progress - James P. Steinberg, MD; Susan E. Coffin, MD, MPH

Influence of State Laws Mandating Reporting of Healthcare-Associated Infections: The Case of Central Line-Associated Bloodstream Infections - Amy L. Pakyz, PharmD, MS; Michael B. Edmond, MD, MPH, MPA

785 Impact of Postplacement Adjustment of Peripherally Inserted Central Catheters on the Risk of Bloodstream Infection and Venous Thrombus Formation - Sanjiv M. Baxi, MD, MS; Emily K. Shuman, MD; Christy A. Scipione, MPH; Benrong Chen, PhD; Aditi Sharma, MD; Jennifer J. K. Rasanathan, MD, MPH; Carol E. Chenoweth, MD, MS

793 Quality Gaps in Documenting Urinary Catheter Use and Infectious Outcomes •

Barbara W. Trautner, MD, PhD; Jan E. Patterson, MD; Nancy J. Petersen, PhD; Sylvia Hysong, PhD;

Deborah Horwitz, PA; G. John Chen, MD, PhD; Patti Grota, RN, PhD; Aanand D. Naik, MD

800 Ventilator-Associated Tracheobronchitis Increases the Length of Intensive Care Unit Stay •

Marios Karvouniaris, MD; Demosthenes Makris, MD, PhD; Efstratios Manoulakas, MD; Paris Zygoulis, MD;

Konstantinos Mantzarlis, MD; Apostolos Triantaris, MD; Maria Chatzi, RN; Epaminondas Zakynthinos, MD, PhD

809 Prevalence and Risk Factors for Acquisition of Carbapenem-Resistant Enterobacteriaceae in the Setting of Endemicity - Mahesh Swaminathan, MD; Saarika Sharma, MD; Stephanie Poliansky Blash, MPH;

Gopi Patel, MD, MS; David B. Banach, MD, MPH; Michael Phillips, MD; Vincent LaBombardi, PhD; Karen F. Anderson; Brandon Kitchel, MS; Arjun Srinivasan, MD; David P. Calfee, MD, MS

818 Multiple Site Surveillance Cultures as a Predictor of Methicillin-Resistant Staphylococcus aureus

Infections - Benedict Lim Heng Sim, MBBS, MRCP; Emma McBryde, MBBS, FRACP, PhD;

Alan C. Street, MBBS, FRACP; Caroline Marshall, MBBS, FRACP, PhD

825 Impact of the 2009 Influenza A (H1N1) Pandemic on Healthcare Workers at a Tertiary Care Center in New York City • Nahid Bhadelia, MD, MA; Rajiv Sonti, MD; Jennifer Wright McCarthy, MD; Jaclyn Vorenkamp, MD, MPH; Haomiao Jia, PhD; Lisa Saiman, MD, MPH; E. Yoko Furuya, MD, MS

\title{
CONCISE COMMUNICATIONS
}

832 Admission Surveillance for Carbapenamase-Producing Enterobacteriaceae at a Long-Term Acute Care Hospital - Jessica D. Lewis, MD; Matthew Bishop, BS; Brenda Heon, RN, BSN; Amy J. Mathers, MD; Kyle B. Enfield, MD, MS; Costi D. Sifri, MD

835 Commentary: Carbapenem-Resistant Enterobacteriaceae, Long-Term Acute Care Hospitals, and Our Distortions of Reality • L. Silvia Munoz-Price, MD

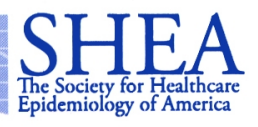

CONTENTS CONTINUED INSIDE

THE OFFICIAL JOURNAL OF THE SOCIETY FOR HEALTHCARE EPIDEMIOLOGY OF AMERICA 
3-5 October 2013 Cincinnati, Ohio USA

Global Conference on Prevention and Management of Surgical Infections

Presented by: International Surgical Infections Study Group (ISIS)

Meet the world's leading experts on surgical infections and take back strategies you can implement immediately to reduce infection and loss of life. We can change surgical outcomes now, one incision at a time.

The conference will focus on:

Surgical Site Infection Prevention Current Global Burden

Regional Concerns

Construction of Surveillance Programs

SSI Prevention Techniques

Is Culture Change the Answer?

Intra-abdominal and Soft Tissue Infections

Disease Spectrum, Management and Results throughout the World

Microbiology of Infections in High, Middle, and

Low-Income Countries

\section{Practical Healthcare Epidemiology अrdedition}

\section{SHEA Texthook}

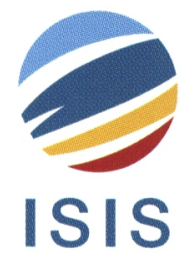

Partnerships for Safe Surgery.

The International Surgical
Infections Study Group was
started to develop strategies
every health care worker can
use to reduce the risks of
surgical infection and loss of
life, and to stretch limited
medical resources by
changing the part of the
hospital that matters most:
Its safety culture.
We are focused on surgical issues
in low- and middle-income countries.
We are currently collaborating with
the World Health Organization to
develop guidelines for the prevention
of surgical site infections. These
guidelines will be a critical tool
for implementing a more focused
safety paradigm.

We are organizing a Safe Surgery Symposium focused on operative site and other surgical infections. We will discuss current practices, procedures, and outcomes in different regions of the world, and outline procedures for improving global patient safety.

The surgeons organizing this society are:

Joseph Solomkin CINCINAAT?, USA

Narcisco Navarro MANILA, PHILPPANES

Edmundo Ferraz RECIFE, BRAZZL.

Jianan Ren

J. Wesley Alexander

Emmanuel Ameh ZARIA, NIGERIA

Daniel Poenaru

Peter Nthumba

Dietmar Wittmann SARASOTA, USA

isis-group.org

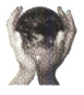

\section{WHO} Clean Care is 


\section{INFECTION CONTROL \& HOSPITAL EPIDEMIOLOGY}

CONTENTS CONTINUED FROM COVER

Discontinuation of Reflex Testing of Stool Samples for Vancomycin-Resistant Enterococci Resulted in Increased Prevalence - Mandy Bodily, RN, MPH, CIC; Kathleen M. McMullen, MPH, CIC; Anthony J. Russo, MPH; Nupur D. Kittur, PhD, MPH; Joan Hoppe-Bauer, BS; David K. Warren, MD, MPH

Evaluation of Methicillin-Resistant Staphylococcus aureus Skin and Soft-Tissue Infection Prevention Strategies at a Military Training Center - Stephanie M. Morrison, MPH; Carl R. Blaesing, MS, MPH; Eugene V. Millar, PhD; Uzo Chukwuma, MPH; Carey D. Schlett, MPH; Kenneth J. Wilkins, PhD; David R. Tribble, MD, DrPH; Michael W. Ellis, MD

847 Is the Use of Antimicrobial Devices to Prevent Infection Correlated across Different HealthcareAssociated Infections? Results from a National Survey • Sanjay Saint, MD, MPH; M. Todd Greene, PhD, MPH; Laura Damschroder, MS, MPH; Sarah L. Krein, PhD, RN

850 An Outbreak of Pseudomonas aeruginosa Respiratory Tract Infections Associated with Intrinsically Contaminated Ultrasound Transmission Gel - Paul Chittick, MD; Victoria Russo, MPH; Matthew Sims, MD, PhD; Barbara Robinson-Dunn, PhD; Susan Oleszkowicz, MPH; Kara Sawarynski, PhD; Kimberly Powell, BS; Jacob Makin, MT; Elizabeth Darnell, MT; Judith A. Boura, MS; Bobby Boyanton, MD; Jeffrey Band, MD

854 Hospital Policies, State Laws, and Healthcare Worker Influenza Vaccination Rates • Richard K. Zimmerman, MD, MPH, MA; Chyongchiou Jeng Lin, PhD; Mahlon Raymund, PhD; Jamie Bialor, MPH, CHES; Patricia M. Sweeney, RN, JD; Mary Patricia Nowalk, PhD, RD

A Road Map to a Comprehensive Regulation on Ventilation Technology for Operating Rooms • Santina Iudicello, PhD; Antonello Fadda, MSc

\section{RESEARCH B RIEFS}

861 Patterns of Nosocomial Infections, Multidrug-Resistant Microorganisms, and Mold Detection after Extensive Black-Water Flooding: A Survey from Central Thailand • Anucha Apisarnthanarak, MD; Thana Khawcharoenporn, MD, MSc; Linda M. Mundy, MD, PhD

The Impact of a Single Ward for Cohorting Patients with Infection due to Multidrug-Resistant Organisms - Diego Jung Stumpfs, RN; Sonia Beatriz Cocaro de Souza, RN, PhD; Loriane Rita Konkewicz, RN, MSc; Carem Gorniak Lovatto, RN, MSc; Cristófer Farias da Silva, PharmaD; Andréia Barcelos Teixeira Macedo, RN; Rodrigo Pires dos Santos, MD, PhD difficile Isolation Rooms - Abhishek Deshpande, MD, PhD; Brett Sitzlar, BS; Dennis Fertelli; Sirisha Kundrapu, MD; Venkata C. K. Sunkesula, MD, MS; Amy J. Ray, MD; Curtis J. Donskey, MD

867 Infection Prevention and Control in the Intensive Care Unit: Open versus Closed Models of Care • Nick Daneman, MD, MSc, FRCPC; Damon C. Scales, MD, PhD, FRCPC; Bernard Lawless, MD, MHSc, FRCSC; John Muscedere, MD, FRCPC; Vanessa Blount, MSc; Robert A. Fowler, MD, MSc, FRCPC 


\section{INFECTION CONTROL \& HOSPITAL EPIDEMIOLOGY}

VOLUME 34 , NUMBER 8

CONTENTS CONTINUED FROM PREVIOUS PAGE

LETTERS TO THE EITOR

872 Use of Statistics as Another Factor Leading to an Overestimation of Chlorhexidine's Role in Skin

Antisepsis - Matthias Maiwald, MD, PhD; Trevor N. Petney, PhD; Pryseley N. Assam, PhD; Edwin S.-Y. Chan, PhD

873 Reply to Maiwald et al • Pracha Nuntnarumit, MD; Nartsiri Sangsuksawang, MD 


\author{
An Official Publication of the Society for Healthcare Epidemiology of America
}

EDITOR

Suzanne F. Bradley, MD • Ann Arbor, MI

\section{DEPUTY EDITOR}

Carol A. Kauffman, MD • Ann Arbor, MI

\section{SENIOR ASSOCIATE EDITORS}

C. Glen Mayhall, MD $\bullet$ Galveston, TX

Gina Pugliese, RN, MS • Chicago, IL

William Schaffner, MD $\cdot$ Nashville, TN

\section{ASSOCIATE EDITORS}

Carol Chenoweth, MD - Ann Arbor, MI

Ebbing Lautenbach, MD, MPH $\cdot$ Philadelphia, PA

David Weber, MD, MPH • Chapel Hill, NC

\section{STATISTICS CONSULTANT}

Rodney L. Dunn, MS • Ann Arbor, MI

\section{SECTION EDITOR FOR GUIDELINES, POSITION} PAPERS, AND INVITED REVIEWS

Eli Perencevich, MD, MS • Iowa City, IA

\section{MANAGING EDITOR}

Rob Blixt • Chicago, IL

\section{PAST EDITORS}

Infection Control

Richard P. Wenzel, MD, 1980-1990 (vols. 1-11)

Infection Control and Hospital Epidemiology

Richard P. Wenzel, MD, 1991-1992 (vols. 12 and 13)

Michael D. Decker, MD, 1993-2001 (vols. 14-22)

Barry M. Farr, MD, 2002-2004 (vols. 23-25)

William R. Jarvis, MD, 2005-2006 (vols. 26 and 27)

\section{EDITORIAL ADVISORY BOARD}

Miriam Alter, $\mathrm{PhD}, \mathrm{MD} \cdot$ Galveston, TX

Deverick Anderson, MD, MPH $\bullet$ Durham, NC Anucha Apisarnthanarak, MD - Pratumthani, Thailand

Lennox Archibald, MD, FRCP • Alachua, FL

Hilary Babcock, MD - St. Louis, MO

Shailen Baneriee, $\mathrm{PhD} \cdot$ Atlanta, GA

Elise M. Beltrami, MD, MPH - Atlanta, GA Jo Anne Bennett, $\mathrm{RN}, \mathrm{PhD} \cdot$ New York, NY David Birnbaum, PhD, MPH • Sidney, BC Marc Bonten, MD - Utrecht, Netherlands Christian Brun-Buisson, MD - Creteil, France John P. Burke, MD - Salt Lake City, UT David P. Calfee, MD, MS • New York, NY Yehuda Carmeli, MD, MPH - Tel Aviv, Israel Donald E. Craven, MD - Burlington, MA Christopher Crnich, MD, MS • Madison, WI Erika D'Agata, MD, MPH $\bullet$ Boston, MA Daniel Diekema, MD - Iowa City, IA Erik Dubberke, MD, MSPH • St. Louis, MO Charles E. Edmiston, Jr., PhD • Milwaukee, WI Theodore C. Eickhoff, MD - Denver, CO Mohamad Fakih, MD, MPH • Grosse Pointe Woods, MI Jon $\mathrm{P}$. Furuno, $\mathrm{PhD} \cdot$ Portland, $\mathrm{OR}$ Petra Gastmeier, MD • Berlin, Germany Jeffrey Gerber, $\mathrm{MD}, \mathrm{PhD} \cdot$ Philadelphia, PA Dale N. Gerding, MD - Hines, IL

Donald A. Goldmann, MD • Boston, MA Nicholas Graves, $\mathrm{PhD} \cdot$ Brisbane, Australia Donna Haiduven, RN, PhD, CIC - Tampa, FL Anthony D. Harris, MD, MPH - Baltimore, MD Elizabeth Henderson, $\mathrm{PhD} \bullet$ Calgary, $\mathrm{AB}$ David K. Henderson, MD $\bullet$ Bethesda, MD Loreen A. Herwaldt, MD • Iowa City, IA
Peter N. R. Heseltine, $\mathrm{MD} \cdot \mathrm{Brea}, \mathrm{CA}$ John A. Jernigan, MD, MS - Atlanta, GA James T. Lee, $\mathrm{MD}, \mathrm{PhD} \cdot$ St. Paul, MN L. Clifford McDonald, MD - Atlanta, GA Allison McGeer, MD - Toronto, ON Leonard A. Mermel, DO, ScM • Providence, RI Robert R. Muder, MD - Pittsburgh, PA Linda Mundy, MD • Collegeville, PA Joseph M. Mylotte, MD, CIC • Buffalo, NY Jan Evans Patterson, MD $\bullet$ San Antonio, TX David A. Pegues, MD - Los Angeles, CA Didier Pittet, MD, MS • Geneva, Switzerland Issam Raad, MD $\cdot$ Houston, TX Manfred L. Rotter, MD, DipBact • Vienna, Austria William A. Rutala, PhD, MPH - Chapel Hill, NC Lisa Saiman, MD, MPH $\bullet$ New York, NY Sanjay Saint, MD, MPH • Ann Arbor, MI Sorana Segal-Maurer, $\mathrm{MD} \cdot$ Flushing, $\mathrm{NY}$ Lynne M. Sehulster, PhD $\cdot$ Atlanta, GA John A. Sellick, DO $\cdot$ Amherst, NY Kent Sepkowitz, MD • New York, NY Andrew E. Simor, MD - Toronto, ON Philip W. Smith, MD • Omaha, NE Kurt Stevenson, MD, MPH $\bullet$ Columbus, OH Nimalie Stone, MD - Atlanta, GA Thomas Talbot, MD, MPH $\bullet$ Nashville, TN Paul Tambyah, MBBS - Singapore William Trick, MD - Chicago, IL Antoni Trilla, MD, $\mathrm{PhD} \cdot$ Barcelona, Spain Robert A. Weinstein, MD $\cdot$ Chicago, IL Andreas Widmer, MD, MS $\bullet$ Basel, Switzerland Marcus Zervos, MD • Detroit, MI
Infection Control and Hospital Epidemiology (ISSN 0899-823X) is published monthly by the University of Chicago Press, 1427 E. 60th St., Chicago, IL 60637-2954 (http://www .journals,uchicago.edu//CHE/). The editorial office is in Chicago, Illinois.

\section{Editorial Office}

Communications should be addressed to the Editor, Infection Control and Hospita Epidemiology, 1427 E. 60th St., Chicago, IL 60637-2954 (e-mail: iche@press.uchicago.edu; telephone: 773-702-2538, fax: 773-753-4247). Contributors should consult the Information for Authors, which is available at the journal's Web site.

\section{Advertising}

Please direct advertising inquiries to Paul Tucker, Breuning Nagle Associates, 59 Grove Street, New Canaan, CT 06840 (e-mail: paul@bnal.com; telephone: 847-669-1096, fax 203-801-0011). Publication of an advertisement in Infection Control and Hospital Epidemiology does not imply endorsement of its claims by the Society for Healthcare Epidemiology of America, by the Editor, or by the University of Chicago. Correspondence regarding advertising should be addressed to the advertising office in Chicago.

\section{Permissions}

Articles may be copied or otherwise reused without permission only to the extent permitted by Sections 107 and 108 of the US Copyright Law. Permission to copy articles for personal, internal, classroom, or library use may be obtained from the Copyright Clearance Center (http://www.copyright.com). For all other uses, such as copying for general distribution, for advertising or promotional purposes, for creating new collective works, or for resale, please contact the Permissions Coordinator, Journals Division, University of Chicago Press 1427 E. 60th St., Chicago, IL 60637 (e-mail: journalpermissions@press.uchicago.edu; fax:
773-834-3489). Articles in the public domain may be used without permission, but it is customary to contact the author.

\section{Subscriptions}

The individual subscription rate for 2013 is $\$ 191$. Lower rates for fellows, residents, and students are available at http://www.journals.uchicago.edu//CHE. Individuals have the option to order directly from the University of Chicago Press. Institutional print + electronic and e-only subscriptions are available through ISTOR's Current Scholarship Program and include unlimited online access; rates are tiered according to an institution's type and research output: $\$ 455$ to $\$ 1,438$ (print + electronic), $\$ 364$ to $\$ 910$ (e-only). Institutional print-only is $\$ 455$. Additional taxes and/or postage for non-U.S. subscriptions may apply. Subscription agent for Japan: Kinokuniya Company, Ltd. Free or deeply discounted access is available in most developing nations through the Chicago Emerging Nations Initiative (http://www.journals.uchicago.edu/ceni/).

Please direct subscription inquries, requests for back issues, and address changes to Journals Division, University of Chicago Press, P.O. Box 37005, Chicago, IL 60637 (e-mail: subscriptions@press.uchicago.edu; telephone: 773-753-3347 or toll-free in the United States and Canada 877-705-1878; fax: 773-753-0811 or toli-free 877-705-1879).

Postmaster: Send address changes to Infection Control and Hospital Epidemiology, University of Chicago Press, P.O. Box 37005, Chicago, IL 60637-2954.

Periodicals postage paid at Chicago, Illinois, and at an additional mailing office.

Published by the University of Chicago Press, Chicago, Illinois. (C) 2013 by The Society for Healthcare Epidemiology of America. All rights reserved. This publication is printed on acid-free paper. 

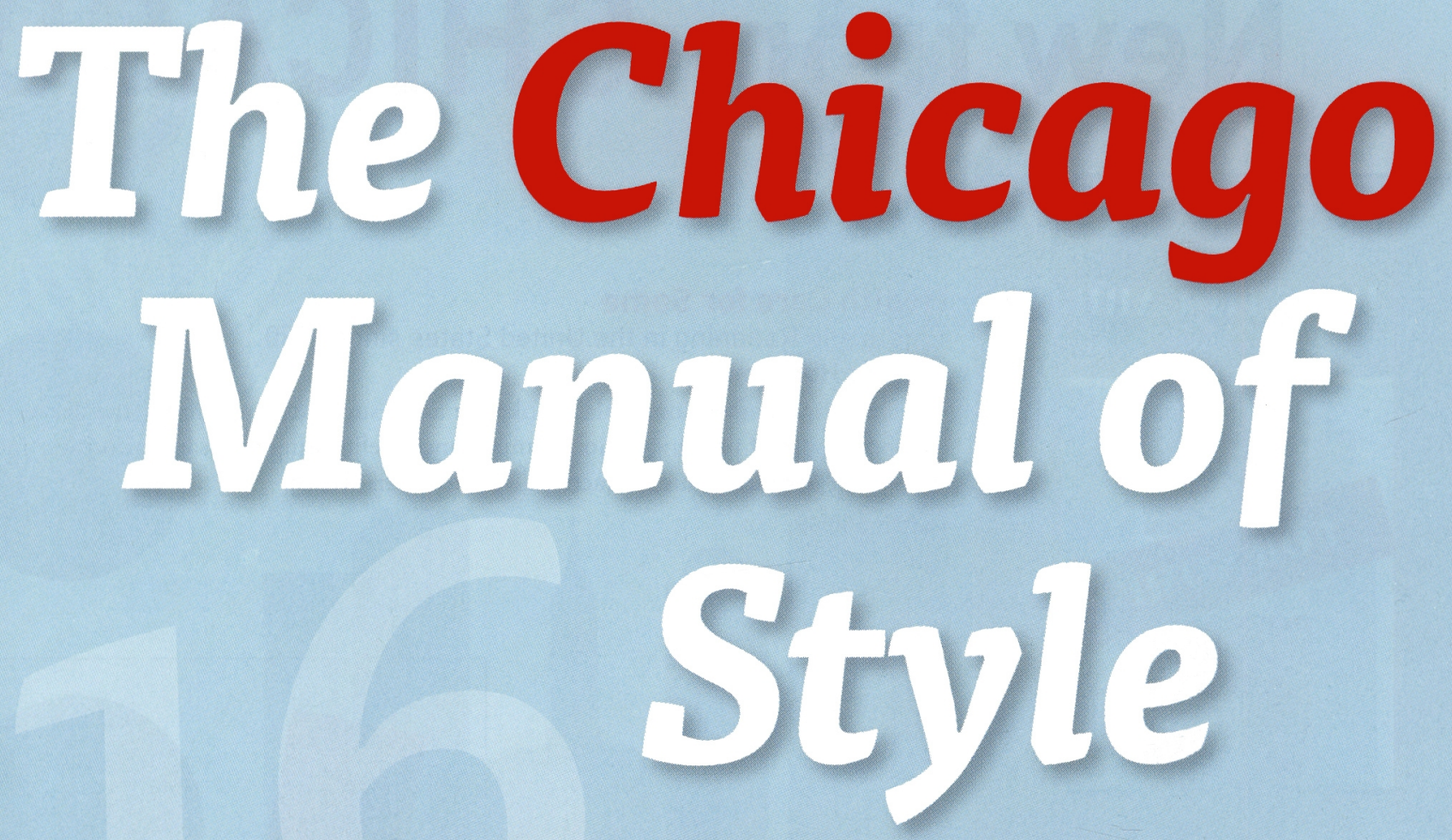

\section{SIXTEENTH EDITION}

"The Sixteenth Edition of The Chicago Manual of Style is here, and it's hard for some of us to contain our excitement. ... For those of us who spend our days worrying over words, there really is something thrilling — or at least comforting — about the arrival

of the newest incarnation of this venerable guide."

-New Yorker Book Bench Blog

Cloth $\$ 65.00$

The Chicago Manual of Style Online is available by annual subscription. Sign up for a thirty-day FREE trial at www.chicagomanualofstyle.org 


\section{New from CHICAGO}

\section{IIEALTII CARE}

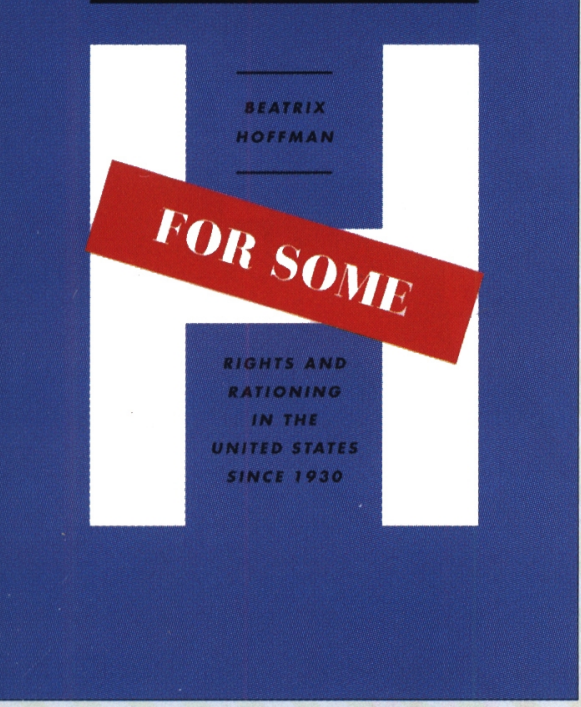

\section{A Philosophical Defense of Clinical Reasoning}

"Drawing on philosophy, science, ethics, and a wealth of personal experience as a physician and philosopher, Hillel D. Braude offers keen insight into the essence of medicine as an intellectual and moral endeavor."-James Giordano,

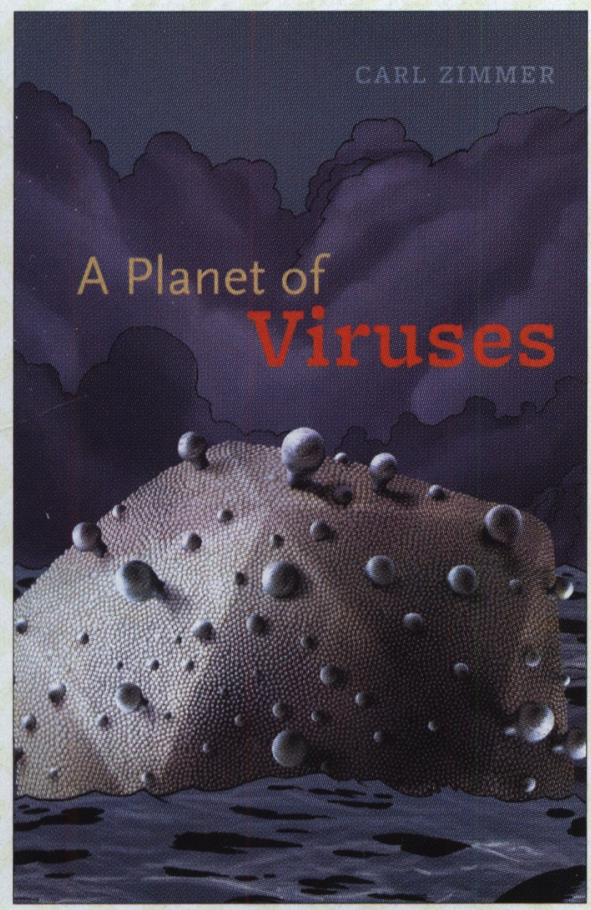

Hillel D. Braude University of Oxford

CLOTH $\$ 45.00$

Health Care for Some

Rights and Rationing in the United States since 1930

\section{Beatrix Hoffman}

"Beatrix Hoffman's rational, plainspoken analysis succeeds in clarifying the discourse a topic of pressing national importance, delineating partisans' priorities, and ing the numerous distractions."-Publishers Weekly

CLOTH $\$ 30.00$

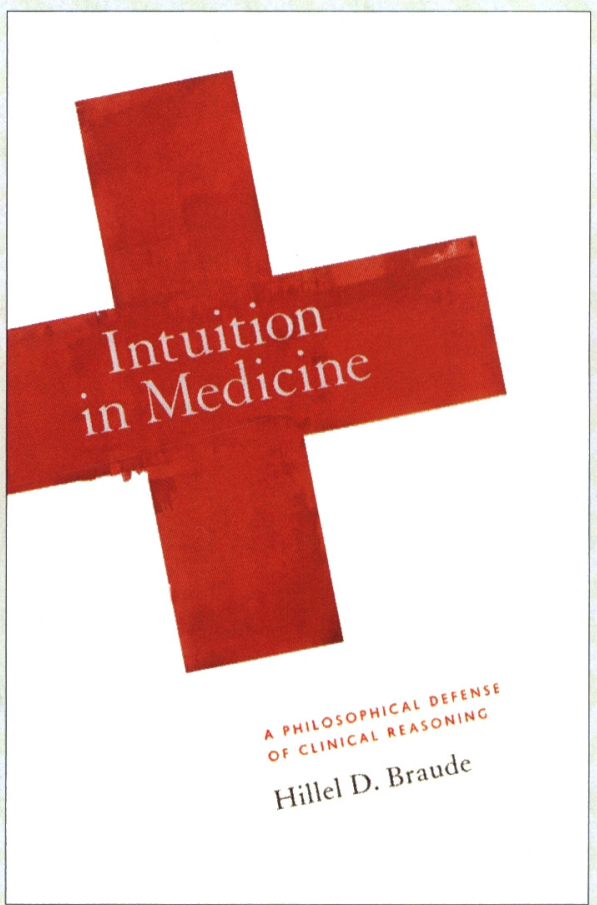

\section{Now in Paperback}

\section{A Planet of Viruses}

\section{Carl Zimmer}

"This book is pure reading pleasure. It is amazing how seamlessly Carl Zimmer tells the stories of viruses in short chapters, describing the history, microbiology, and impacts of viruses in interesting, informative, readable chapters."-Microbe Magazine PAPER $\$ 12.00$ 


\section{Join SHEA}

Access to the information you need to meet the infection prevention challenges ahead.

- One year subscription to Infection Control \& Hospital Epidemiology

- Online access to Infection Control \& Hospital Epidemiology

- Monthly newsletter with abstracts of scientific journal articles and current events

- Online job board

- Online member search

- Continuing Medical Education (CME) and Continuing Nursing Education (CNE) opportunities

\section{About SHEA}

The Society for Healthcare Epidemiology of America (SHEA) was founded in 1980 to advance the science of healthcare epidemiology and infection prevention. SHEA works to maintain the utmost quality of patient care and healthcare worker safety in all healthcare settings, applying epidemiologic principles and prevention strategies to a wide range of quality-of-care issues. SHEA is strengthened by its active membership in all branches of medicine, public health, and healthcare epidemiology. The Society's expertise is sought by healthcare regulatory and accrediting agencies, and its scientific voice is influential in guiding decision-making bodies towards rational, effective, cost-conscious policies.

\section{Mission}

SHEA's mission is to prevent and control healthcare-associated infections and advance the field of healthcare epidemiology.

\section{Core Values}

\section{SHEA as an organization:}

- Advances the science of healthcare epidemiology through research and education

- Translates knowledge into effective policy and practice

- Mentors, trains and promotes professional development in healthcare epidemiology

- Collaborates and shares expertise with other organizations

- Adheres to high ethical standards and promotes honesty and ethical principles in the practice of epidemiology

\section{Areas of Focus}

- Epidemiologic research and laboratory investigation

- Applying the best evidence for protecting patients and reporting data

- Risk reduction programs focused on device and procedure management

- Policy development and implementation

- Education and information

Please contact info@shea-online.org with membership inquiries.

\section{Join SHEA at www.shea-online.org}

